\title{
Relasi Struktur Kelas Sosial Marx dalam Naskah Drama "Kocak-Kacik" dan "Kapai-Kapai" Karya Arifin C. Noer
}

\author{
Tio Zulfan Amri \\ Program Studi Pendidikan Bahasa dan Sastra Indonesia, \\ Fakultas Bahas dan Seni, Universitas Indraprasta PGRI \\ tio.zulfan.amri@gmail.com
}

\begin{abstract}
Abstrak
Penelitian ini bertujuan untuk mengetahui dan memahami lebih dalam unsur tokoh-tokoh utama dalam drama "Kocak-Kacik" dan "Kapai-Kapai" Karya Arifin C. Noer. Dalam penelitian ini peneliti menggunakan metode pendekatan deskriptif kualitatif yang bersifat mengumpulkan data berupa kutipan yang terdapat dalam naskah drama "Kocak-Kacik" dan "Kapai-Kapai" Karya Arifin C. Noer melalui pendekatan sosiologi sastra Karl Marx. Penelitian ini membahas unsur intrinsik yaitu tentang tokoh-tokoh utama dalam naskah drama. Peneliti tertarik meneliti konflik yang terjadi pada tokoh utama yang menyebabkan terjadinya perang dingin. Penting untuk meneliti lebih lanjut tokoh utama yang terdapat dalam naskah tersebut, agar dapat dijadikan sebagai inspirasi dan bahan renungan dalam menjalani realitas kehidupan para penikmat karya sastra. Dalam penelitian ini juga akan membahas tentang konflik antarkelas yang merupakan hasil dari aktivitas dan tingkah laku manusia. Konflik hadir dalam sebuah cerita dalam bentuk pertentangan, ketegangan, kesedihan, kekecewaan batin yang dialami oleh antartokohnya. Pada kajian tokoh utama dalam naskah drama tersebut terdapat konflik antarkelas sosial, frustrasi, dan agresivitas
\end{abstract}

Kata Kunci: tokoh utama, relasi struktur sosial, naskah drama

\begin{abstract}
This study aims to find out and understand more deeply the elements of the main figures of "Kocak-Kacik" and "Kapai-Kapai" by Arifin C. Noer. In this study, researchers used a descriptive qualitative approach that is collecting data in the form of quotations contained in the play script "Kocak-Kacik" and "Kapai-Kapai" by Arifin C. Noer through Karl Marx's literary sociology approach. This research discusses intrinsic elements, which are about the main characters in the drama script "Kocak-Kacik" and "Kapai-Kapai". Researchers are interested in examining the conflicts that occur in the main character that caused the cold war. It is important to examine further the main characters contained in the play script "Kocak-Kacik" and "Kapai-Kapai", so that it can be used as inspiration and reflection in living the realities of the lives of the connoisseurs of his work. Researchers will also discuss class-to-class conflict that is the result of human activity and behavior. Conflicts present in a story in the form of conflict, tension, sadness, inner disappointment experienced by the characters. In the research of the main characters in the play there are conflicts between social classes, frustration, and aggressiveness.
\end{abstract}

Keywords: the main character, relationship structure of social classes, play script. 


\section{PENDAHULUAN}

Sastra merupakan cerminan atau gambaran mengenai kenyataan, tetapi dunia melukiskan banyak hal, pada kenyataannya tidak pernah ada atau ada. Sastra adalah kegiatan kreatif sebuah karya seni yang bentuk dan ekspresinya imajinatif. Sastra dibungkus dengan bahasa indah dan artistik sehingga menarik bagi pembaca.

Manusia menggunakan karya sastra sebagai sarana untuk mengungkapkan gagasan, pengalaman, pemikiran dan sebagainya. Karya sastra cenderung memantulkan keadaan masyarakat, mau tidak mau akan menjadi saksi zaman. Dalam hal ini, sebenarnya pengarang ingin berupaya untuk mendokumentasikan zaman dan sekaligus sebagai alat komunikasi antara pengarang dan pembacanya. Pengarang sebagai seorang pengirim pesan akan menyampaikan berita zaman lewat cermin dalam teks kepada penerima pesan.

Karya sastra dapat memperkaya dan memperluas emosi-emosi pembaca. Karya sastra dapat menumbuhkan emosi manusia seperti rasa sayang, simpati, sedih dan lainlainnya. Dengan membaca karya sastra, pembaca dibawa terbang mengembara dan berkreasi.

Karya sastra berbentuk apa pun pasti mempunyai pesan-pesan tersembunyi baik unsur moral, etika, sosial, politik, dan lain-lainnya. Terlebih drama yang sarat akan makna-makna, penikmat drama pertunjukan ketika melihat, mempunyai gambaran bagaimana pertunjukan drama itu, apakah kesannya sampai atau tidak.

Dalam karya sastra, tokoh merupakan elemen yang sangat penting. Tokoh dapat membangun dan menghidupkan sebuah karya sastra. Setiap tokoh mempunyai karakter yang berbeda-beda yang dapat dijadikan inspirasi bagi para pembacanya karena masingmasing tokoh membawa pesan termasuk dalam drama.

Yang menarik dari drama adalah seluruh indra bekerja untuk menerima persepsi yang ditangkap mata, telinga, dan diolah melalui akal (logos). Seni pertunjukan drama di Indonesia ada dua, tradisional dan modern. Seni pertunjukan tradisional adalah bentuk pertunjukan seni yang pemainnya berasal dari daerah setempat karena terkondisi dengan adat istiadat setempat, sosial masyarakat dan struktur geografis masing-masing daerah.

Manusia pada dasarnya terpengaruh aspek sosial dalam berinteraksi, menimbulkan kesenjangan di antaranya individu atau kelompok dan ini menyebabkan banyak konflik. Seperti halnya pada Arifin C. Noer, beliau menulis naskah "KocakKacik" bermula dari kegelisahan melihat fenomena terjadi pada tahun 70-an itu. Pada era orde baru, sebagaimana diketahui Soeharto memimpin secara diktator, semua aturan dibuat untuk kepentingan pribadi serta dibungkam kebebasan berpendapat. Hal tersebut membuat seorang Arifin C. Noer gelisah terhadap fenomena yang terjadi.

Teater tidak bisa lepas dari lingkungan sosialnya dan lingkungan sosial itu sendiri sangat berpengaruh atas terjadinya sebuah konflik yang melahirkan cerita. Teater merupakan sebuah bentuk pertunjukan yang merujuk ke realitas kehidupan manusia, kemudian divisualisasikan ke atas panggung dan dijadikan sebuah drama. Lakon "Kocak Kacik" karya Arifin C. Noer yang menceritakan sosok tokoh Darim yang selalu mendapatkan ketertindasan atau pertentangan dengan kenyataan hidup yang serba materialistik. Manusia akan rusak jika teknologi sudah dipakai tidak pada tempatnya.

Pada penelitian ini mengacu pada beberapa teori, agar terjadi penafsiran yang sama terhadap istilah-istilah yang digunakan dalam penelitian, seperti naskah drama, penokohan, relasi antarkelas sosial. 
Naskah drama adalah bagian salah satu hasil karya sastra di samping puisi, prosa, dan lain-lainnya. Naskah drama merupakan bahan dasar sebuah pementasan dan belum sempurna bentuknya apabila belum dipentaskan. Naskah drama adalah salah satu genre karya sastra yang sejajar dengan prosa dan puisi. Berbeda dengan prosa maupun puisi, naskah drama memiliki bentuk sendiri yaitu ditulis dalam bentuk dialog yang didasarkan atas konflik batin dan mempunyai kemungkinan dipentaskan. Naskah drama juga sebagai ungkapan pernyataan (play wright) yang berisi nilai-nilai pengalaman umum juga merupakan ide dasar bagi aktor. Naskah drama (lakon) pada umumnya disebut skenario, berupa susunan (komposisi) dari adegan-adegan dalam penuangan sebagai karya tulis, biasanya memiliki keterbatasan sesuai dengan fitrahnya.

Pementasan naskah drama dikenal dengan istilah teater. Dapat dikatakan bahwa drama berupa cerita yang diperagakan para pemain di panggung. Selanjutnya, dalam pengertian kita sekarang, yang dimaksud drama adalah cerita yang diperagakan di panggung berdasarkan naskah.

Intinya, pemahaman drama adalah karya tulis untuk teater, setiap situasi mempunyai konflik dan penyelesaian cerita, jenis sastra berbentuk dialog untuk dipertunjukkan di atas pentas. Jadi, pengertian drama adalah hasil seni sastra (naskah) yang ungkapannya dalam wujud teater menekankan kepada kekuatan unsur suara (kata, ucapan, dialog) baik yang tersirat maupun tersurat (Riantiarno, 2011: 4). Meskipun merupakan satu bentuk kesusastraan, cara penyajian drama berbeda dari bentuk kesusastraan lainnya. Novel, cerpen, dan balada masing-masing menceritakan kisah yang melibatkan tokoh-tokoh lewat kombinasi antara dialog dan narasi.

Ada tiga macam teori yang mempersoalkan asal-muasal drama. Menurut Brockett (dalam Riantiarno 2011: 20), drama mungkin telah berkembang dari upacara religius primitif yang dipentaskan untuk meminta pertolongan dewa. Upacara ini mengandung banyak benih drama. Para pendeta sering memerankan makhluk super alami atau binatang, kadang-kadang meniru akting berburu. Teori kedua memberi kesan bahwa himne pujian dinyanyikan bersama di depan makam seorang pahlawan. Pembicara memisahkan diri dari koor dan memperagakan perbuatan-perbuatan dalam kehidupan pahlawan. Teori ketiga memberi kesan drama tumbuh dari kecintaan manusia untuk bercerita. Kisah-kisah yang diceritakan di sekeliling api perkemahan menciptakan kembali kisah-kisah perburuan dan peperangan, atau perbuatan gagah seorang pahlawan yang telah gugur. Ketiga teori tersebut adalah cikal bakal dari drama, tetapi inti dari drama adalah action atau act, yang artinya melakukan.

Tokoh adalah para pelaku atau subjek lirik dalam karya fiksi. Tokoh, berdasarkan bentuknya dapat dibedakan menjadi dua, yaitu tokoh fisik dan tokoh imajiner dan karakter tokoh digambarkan melalui dialog dan lakuan para tokoh sentral, tokoh bawahan, dan tokoh latar pun dijumpai di dalam drama. Dalam drama bisa dijumpai pula tokoh protagonis dan antagonis.

Tokoh protagonis adalah tokoh yang kita kagumi, salah satu jenisnya secara popular disebut tokoh pahlawan yang merupakan pengejawantahan norma-norma nilainilai yang ideal. Tokoh protagonis menampilkan sesuatu yang sesuai dengan pandangan, harapan-harapan, harapan pembaca. Tokoh ini sering dikenali memiliki kesamaan dengan khalayak, permasalahan yang dihadapinya seolah-olah juga sebagai permasalahan umum, demikian pula halnya menyikapinya. Pendek kata, segala yang dirasa, dipikir, dan dilakukan tokoh itu sekaligus mewakili audiens. Identifikasi diri terhadap tokoh demikian merupakan empati yang diberikan oleh pembaca, sedangkan 
tokoh antagonis adalah tokoh yang beroposisi dengan tokoh protagonis, secara langsung ataupun tidak langsung, bersifat fisik ataupun batin (Nurgiyantoro, 2013: 260).

Pembagian tokoh berdasarkan fungsinya, tokoh dibedakan atas tokoh utama dan tokoh bawahan atau pembantu. Tokoh utama adalah tokoh yang memegang peran utama, frekuensi kemunculannya sangat tinggi, menjadi pusat penceritaan, sedangkan tokoh bawahan adalah tokoh yang mendukung tokoh utama yang membuat cerita lebih hidup (Priyatni, 2010: 110). Tokoh dalam drama mengacu pada watak (sifat-sifat pribadi seorang pelaku, sementara aktor atau pelaku mengacu pada peran yang bertindak atau berbicara dalam hubungannya dengan alur peristiwa. Cara mengemukakan watak di dalam drama lebih banyak bersifat tidak langsung, tetapi melalui dialog dan lakuan. Hal ini berbeda dengan yang terjadi dalam novel, watak tokoh cenderung disampaikan secara langsung.

Dalam drama, watak, pelaku dapat diketahui dari perbuatan dan tindakan yang mereka lakukan, dari reaksi mereka terhadap sesuatu situasi tertentu terutama situasisituasi yang kritis, dari sikap mereka menghadapi suatu situasi atau peristiwa atau watak tokoh lain. Di samping itu, watak juga terlihat dari kata-kata yang diucapkan. Dalam hal ini ada dua cara untuk mengungkapkan watak lewat kata-kata (dialog). Pertama, dari kata-kata yang diucapkan sendiri oleh pelaku dalam percakapannya dengan pelaku lain. Kedua, melalui kata-kata yang diucapkan pelaku lain mengenai diri pelaku tertentu.

Nurgiyantoro (2013: 258-278) tokoh-tokoh cerita dalam sebuah cerita fiksi dapat dibedakan ke dalam beberapa jenis penamaan berdasarkan sudut pandang mana penamaan itu dilakukan. Berdasarkan sudut pandang dan tinjuan tertentu, seorang tokoh dapat dikategorikan ke dalam beberapa jenis, misalnya sebagai tokoh utama protagonis berkembang tipikal.

Sastra merupakan pencerminan masyarakat. Melalui karya sastra, seorang pengarang mengungkapkan problema kehidupan. Karya sastra menerima pengaruh dari masyarakat dan sekaligus mampu memberi pengaruh terhadap masyarakat. Sosiologi dapat diartikan sebagai ilmu atau pengetahuan yang sistematis tentang kehidupan berkelompok manusia dalam hubungannya dengan manusia-manusia lainnya yang secara umum disebut masyarakat.

Sosiologi sastra merupakan kajian ilmiah dan objektif mengenai manusia dalam masyarakat, mengenai lembaga dan proses sosial. Sosiologi mengkaji struktur sosial dan proses sosial termasuk di dalamnya perubahan-perubahan sosial yang mempelajari lembaga sosial, agama, ekonomi, politik, dan sebagainya secara bersamaan serta membentuk struktur sosial guna memperoleh gambaran tentang cara-cara manusia menyesuaikan diri dengan lingkungannya, dan mekanisme kemasyarakatan dan kebudayaan.

Setiap anggota masyarakat memiliki hak untuk memberi tanggapan terhadap kondisi sosial masyarakat dalam bentuk karya sastra dan menyuarakan tanggapannya yang berbentuk kritik sosial, ia menjadi wakil masyarakat yang mengemukakan keluhan dan harapan masyarakat. Keluhan dan harapan terjadi karena realitas sosial berada pada ketidaksesuaian dari apa yang diharapkan sehingga memunculkan kritik sosial yang dikemukakan melalui berbagai media yang salah satunya adalah karya sastra.

Kritik sosial termasuk dalam ilmu sastra, pada umumnya memperoleh masukan melalui sudut pandang Karl Marx, bahwa ide, konsep dan pandangan dunia individu ditentukan oleh keberadaan sosialnya. Kenyataan yang demikian dibangun secara sosial, kenyataan dengan kualitas mandiri yang tidak bergantung dari kehendak subjek. Dalam arti bahwa kritik sosial menjadi sarana komunikasi gagasan-gagasan baru sembari 
menilai gagasan lama untuk perubahan sosial. Dengan adanya kritik sosial diharapkan terjadi perubahan sosial ke arah yang lebih baik.

Kritik sosial yang baik hendaknya tidak hanya berisi celaan, kecaman, atau tanggapan yang hanya bersifat negatif, tetapi juga berisi solusi sosial sehingga tercapainya harmonisasi sosial. Menuangkan kritik sosial dalam bentuk karya sastra adalah salah satu bentuk penyampaian kritik sosial secara tidak langsung terhadap kondisi sosial yang sedang terjadi. Hal-hal yang bersangkutan dengan sastra diberi aturan dengan jelas, tetapi diteliti dengan metode-metode dari ilmu sosiologi. Tentu saja ilmu sastra dapat mempergunakan hasil sosiologi sastra, khususnya bila ingin melihat persepsi para pembaca.

Marx (dalam Kurniawan, 2012: 40) mengembangkan teori sosial sastranya dengan menyatakan bahwa kegiatan manusia yang paling penting adalah kegiatan ekonomi (produksi unsur-unsur materi). Hal ini menunjukkan kerangka kerja sosiologi yang bersifat material, yaitu ekonomi menjadi faktor determinasi kehidupan manusia dengan struktur sosial masyarakat. Dalam pandangan Marx, kerja itu merupakan sifat dasar manusia karena aktivitas kerja yang dilakukan membedakannya dengan makhluk hidup lain.

Hal ini sesuai dengan pendapat Ritzer dan Goodman (2011:53) yang menyatakan bahwa yang dimaksud dengan kerja, yaitu objektivasi tujuan manusia, pembentukan suatu relasi yang esensial antara kebutuhan manusia dengan objek-objek material kebutuhan manusia, dan transformasi sifat dasar manusia.

Marx tidak membatasi kerja pada hal yang berhubungan dengan aktivitas ekonomi saja, tetapi memiliki pengertian yang luas. Menurutnya, kerja itu mencakup tindakan-tindakan produktif manusia dalam mengubah dan mengolah alam material untuk tujuan manusia itu sendiri. Aktivitas ekonomi, material, produksi merupakan dasar dari kehidupan manusia dan kehidupan ini menjadikan manusia memproduksi pikiran dan perasaannya. Hal ini menunjukkan bahwa ekonomi menjadi faktor determinasi produksi pikiran dan kesadaran manusia. Marx meyakini bahwa situasi dan kondisi sosial manusia sangat dipengaruhi oleh aspek material-produksi berdasarkan penjelasan di atas. Hal tersebut membuat Marx membagi masyarakat dalam dua struktur, yaitu infrastruktur (basis ekonomi) dan superstruktur (produk pikiran dan perasaan).

Infrastruktur merupakan struktur yang menjadi arsitek (determinasi) yang merancang dan menentukan kehidupan manusia, terutama pikiran dan perasaannya. Superstruktur merupakan kategori sisa atau hasil yang diciptakan oleh infrastruktur yang terdiri dari lembaga-lembaga sosial dan ideologi yang berkembang di masyarakat (Abercombie, 2010: 38).

Marx mengidentifikasi struktur sosial masyarakat menjadi dua kelas, yaitu kelas atas dan kelas bawah yang faktor utamanya didasarkan pada penguasaan alat-alat produksi pada zamannya. Kelas atas adalah kelas yang memiliki sarana produksi, sedangkan kelas bawah adalah mereka (kelas) yang tidak memiliki alat-alat produksi. Relasi kelas ini menciptakan kelas dominan dengan subordinat, majikan dengan budak, tuan tanah dengan pelayan, dan borjuis dengan proletariat. Relasi hubungan ini didasarkan pada faktor determinasi ekonomi.

Analisis struktur kelas sosial sastra berfokus pada sastra dalam genre fiksi sehingga analisis struktur ini berkaitan dengan analisis unsur-unsur pembangun cerita. Dengan melihat sastra sebagai dunia yang dimediakan dengan kata, fokus analisis sosiologi sastra adalah pada relasi antartokoh dalam konteks latar sosial dan alur sebagai 
peristiwa. Dari relasi ketiga unsur ini (tokoh, latar, alur), aspek sosiologi yang berfokus pada relasi tokoh sebagai individu yang kolektif bertindak sosial dapat diidentifikasikan (Kurniawan, 2012: 48).

Dalam konteks ini, paradigma yang akan dibahas dalam menganalisis dengan pendekatan Marx ini adalah pada relasi struktur langkah kerja sederhana yang bisa digunakan untuk menganalisis sastra dengan pendekatan teori sosial Marx. Struktur kelas sosial meliputi kelas atas dan kelas bawah, sedangkan relasi struktur kelas sosial meliputi konflik antarkelas sosial, frustrasi, dan agresivitas.

Kelas atas (borjuis), adalah orang-orang yang hidup di kelas ini menggambarkan gaya hidup hedonis. Pola hidup mereka berorientasi pada kesenangan, yang hanya mengejar kesenangan dan kenikmatan. Kelas bawah (proletariat), ada dua definisi untuk istilah proletariat. Pertama, proletariat adalah lapisan sosial paling rendah. Sementara definisi kedua, adalah golongan buruh yang tidak memiliki alat produksi dan hidup dengan menjual tenaga.

Konflik antarkelas sosial, Konflik antarkelas yang tercipta ketika terjadi perseteruan antar tokoh-tokoh berbeda kelas sosialnya. Biasanya terjadi antara perbedaan secara ekonomi, sosial, atau cara berpikir. Frustrasi, dapat diartikan sebagai kekecewaan dalam diri individu, yang disebabkan oleh tidak tercapainya keinginan. Frustrasi juga bisa diartikan sebagai rasa kecewa yang mendalam karena tujuan yang dikehendaki tak kunjung terlaksana. Agresivitas, merupakan salah satu bentuk perilaku yang dimiliki setiap orang dalam Baron dan Byrne (2012:50) mengemukakan, bahwa agresivitas ialah dorongan dasar yang dimiliki manusia, dengan tujuan menyakiti badan atau perasaan orang lain, terlebih perilaku yang bertujuan melukai atau mencelakakan orang lain. Bentuk agresivitas bisa berupa kekerasan secara fisik ataupun verbal.

\section{METODE PENELITIAN}

Jenis penelitian ini adalah penelitian deskriptif. Selain itu, metode yang digunakan dalam penelitian ini adalah metode kualitatif. Bogdan dan Taylor (dalam Moleong, 2004: 3) mendefinisikan bahwa metode kualitatif merupakan prosedur penelitian yang menghasilkan data deskriptif berupa kata-kata tertulis atau lisan dari orang-orang dan perilaku yang dapat diamati. Penerapan metode kualitatif ini bersifat deskriptif yang berarti data yang dihasilkan berupa kata-kata dalam bentuk kutipankutipan. Menurut Moleong (2004: 11), metode kualitatif yang bersifat deskriptif adalah data yang dikumpulkan berupa kata-kata, gambar, dan bukan angka-angka. Penggunaan metode kualitatif bertujuan untuk mencari pengertian yang mendalam tentang suatu gejala, fakta atau realita. Fakta, realita, masalah, gejala serta peristiwa hanya dapat dipahami bila menelusurinya secara mendalam dan tidak terbatas pada pandangan di permukaan saja (Semiawan, 2010: 1).

Objek pada penelitian ini adalah naskah drama "Kocak-Kacik" dan "Kapaikapai" karya Arifin C. Noer. Di samping itu, data yang digunakan pada penelitian ini adalah kutipan dalam naskah drama. Sumber data terebut, diperoleh berdasarkan hasil pengamatan dan penelitian secara saksama.

Sebelum melakukan penelitian, dilakukan pengkajian terlebih dahulu terhadap objek penelitian lewat buku-buku, artikel, dan jurnal penelitian. Agar didapatkan teori dan metode penelitian yang pas untuk membedah objek penelitian tersebut. Studi literatur akan ditempatkan oleh peneliti sebagai suatu tinjauan pustaka yang berisikan tentang ulasan dari penelitian-penelitian terdahulu mengenai objek kajian ini. 
Selanjutnya, peneliti akan melakukan pengamatan terhadap naskah drama "KocakKacik" dan "Kapai-Kapai" karya Arifin C. Noer menggunakan tabel instrumen.

\section{HASIL DAN PEMBAHASAN \\ Deskripsi Informasi Penelitian}

Deskripsi informasi dalam penelitian ini menyajikan informasi yang berkaitan dengan naskah drama "Kocak-Kacik" dan "Kapai-Kapai" karya Arifin C. Noer sebagai objek penelitian. Novel ini memiliki pesan moral, sosial, ekonomi, perjuangan, pengorbanan, dan cinta, serta memiliki nilai motivasi. Unsur relasi antarkelas sosial dalam penelitian ini difokuskan dalam kepribadian tokoh utama yang meliputi konflik antarkelas, frustrasi, dan agresivitas.

\section{Hasil}

\section{Relasi Struktur Kelas Sosial Marx dalam Naskah Drama “Kocak-kacik"}

Fungsi konflik antarkelas sosial ini memicu unsur frustrasi dan agresivitas pada naskah drama "Kocak-Kacik". Menurut peneliti Arifin C. Noer sengaja memunculkan konflik antarkelas tersebut agar tercipta pertunjukan yang menarik ditonton. Ditemukan sebanyak dari 125 kutipan naskah drama "Kocak-Kacik" yang dianalisis terdiri atas unsur konflik antarkelas sosial sebanyak 25 atau 21,6\%, frustrasi 56 atau 48,7\%, agresivitas 34 atau 29,7\%. Aspek yang paling mendominasi adalah 48,7\%, yaitu frustrasi.

Pada naskah drama "Kapai-Kapai" karya Arifin C. Noer dapat disimpulkan bahwa dari 115 kutipan, unsur konflik antarkelas sebanyak 46 atau 36,8\%, frustrasi 41 atau 32,8\%, agresivitas 38 atau 30,4\%. Unsur frustrasi muncul lebih banyak dibandingkan kedua unsur lainnya. Unsur frustrasi mendominasi paling banyak karena tokoh Abu dan Iyem selalu menghadapi kesulitan ekonomi, pada akhirnya tingkat unsur frustrasi meningkat.

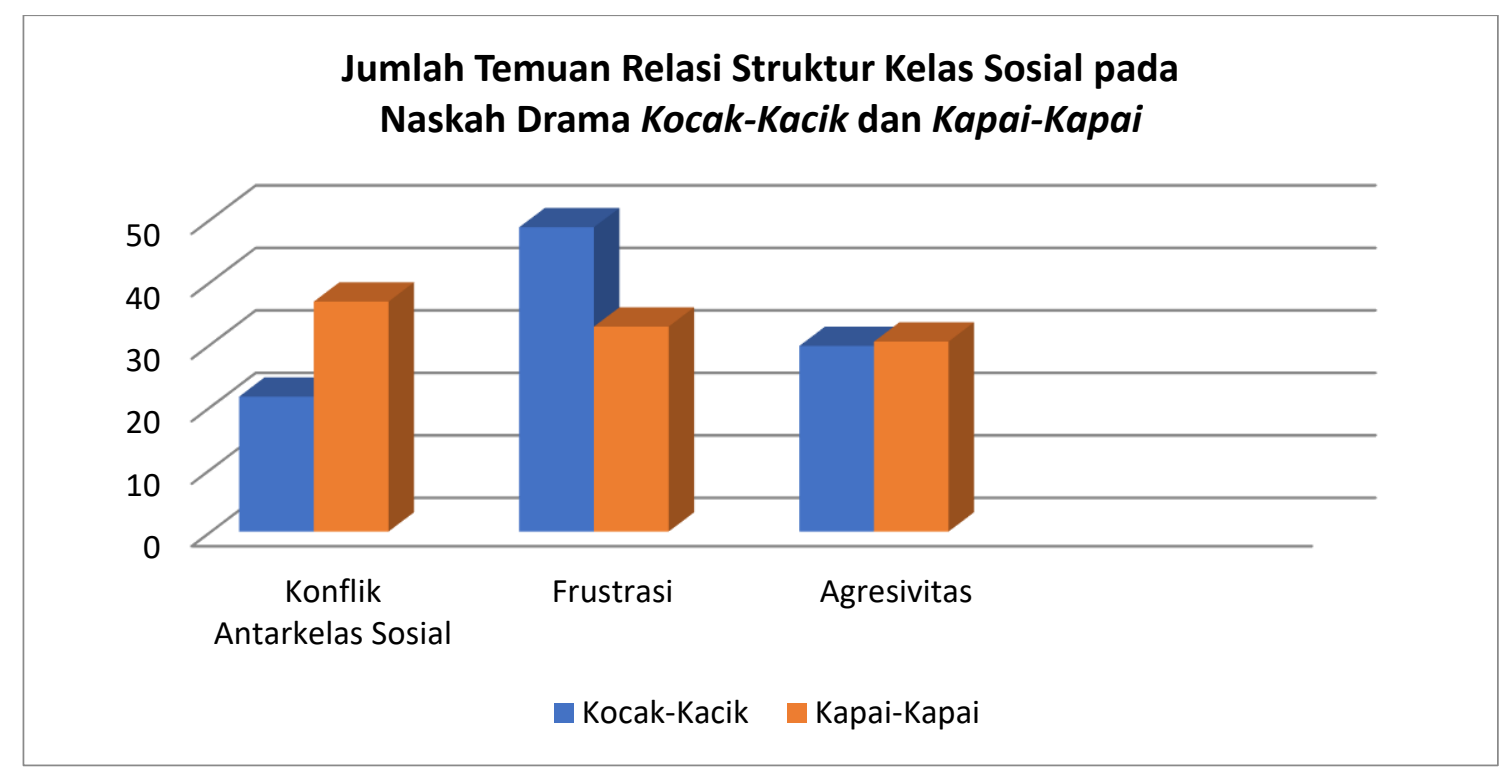

Grafik 1 Relasi Struktur Kelas Sosial dalam Naskah Drama Kocak-Kacik dan Kapai-Kapai 


\section{Pembahasan}

Temuan unsur-unsur relasi struktur kelas sosial yang terdapat dalam naskah drama "Kocak-Kacik" dan "Kapai-Kapai: karya Arifin C. Noer, maka penafsiran dan uraian sebagai berikut.

\section{Unsur Konflik Antarkelas Sosial dalam Naskah Drama "Kocak-Kacik"}

1. Para hadirin, sebagai aktor, sebagai seorang seniman, saya adalah suci, karena saya sama besar dengan hidup alam ini. Menjadi aktor atau seniman bukanlah karena honorarium ataupun idiologi, atau ketenaran atau politik tertentu atau agama tertentu atau lain-lainnya tertentu, tetapi di dorong oleh faktor kesadaran akan perwujudan sebagai jantung masyarakat atau kepuasan nurani masyarakat atau nurani sendiri. Saya minta maaf kalau pidato saya ini, permainan sandiwara ini agak sedikit terganggu. Selanjutnya ijinkanlah saya memainkan peran hakim.

Kutipan termasuk konflik antarkelas, karena konflik yang tercipta ketika terjadi perseteruan antar tokoh-tokoh berbeda kelas sosialnya antara tokoh Hakim, tokoh Darim dan Eroh.

2. Diperlakukan baik malah bingung, baik. Ayo mulai. Panitera, siap.

Kutipan termasuk konflik antarkelas, karena konflik yang tercipta ketika terjadi perseteruan antartokoh berbeda kelas sosialnya antara tokoh Hakim dan tokoh Darim.

3. Saya tidak terima, tuan hakim. Saya mau naik banding

Kutipan termasuk konflik antarkelas, karena konflik yang tercipta ketika terjadi perseteruan antar tokoh-tokoh berbeda kelas sosialnya antara tokoh Hakim dan tokoh Darim.

4. Tapi saya juga menyesal kenapa orang tua saya memberi nama saya Darim, padahal masih banyak nama lain yang mirip dengan itu, seperti Kasim, Rahim, Salim.

Kutipan termasuk konflik antarkelas, karena konflik yang tercipta ketika terjadi perseteruan antar tokoh-tokoh berbeda kelas sosialnya antara tokoh Darim dan Eroh. Persoalan nama Darim yang harus diganti.

5. Kalau begitu kenapa kau tidak ganti nama saja dengan nama Aheng misalnya atau Akiong atau Ahong atau apa.

Kutipan termasuk konflik antarkelas, karena konflik yang tercipta ketika terjadi perseteruan antar tokoh-tokoh berbeda kelas sosialnya antara tokoh Darim dan Eroh. Persoalan nama Darim yang harus diganti.

\section{Unsur Konflik Antarkelas Sosial dalam Naskah Drama "Kapai-Kapai"}

1. (TEPUK TIGA KALI) mana tempolong ludahku (SETELAH MELUDAH KE DALAM TEMPOLONG) Tukang pijat kerajaan segera bawa kemari. Hancur badan saya semalam oleh pesta yang luar biasa. Sudah saya bilang semalam jangan arak dulu tapi kalkun panggang dulu. Ah, jongos goblok semua. Saya sudah bilang ambil kodok dari Majalengka. Bagus mutunya.

Kutipan termasuk konflik antarkelas, karena konflik yang tercipta ketika terjadi perseteruan antar tokoh-tokoh berbeda kelas sosialnya. Abu yang menyuruh tokoh pembantu dalam mimpinya.

2. Siapa? Siapa yang telah mencurinya? Bangsat! Panglima. Siapkan bala tentara. Tiup terompet tanda bahaya. Antarkan bunyinya ke pojok-pojok negara. Gawat. Negara dalam bahaya. Pusaka leluhur dicuri mata-mata setan. Mana? Mana? Kembalikan Cermin Tipu Dayaku!! 
Kutipan termasuk konflik antarkelas, karena konflik yang tercipta ketika terjadi perseteruan antar tokoh-tokoh berbeda kelas sosialnya.

3. Saya yakin saya akan tetap gesit bekerja sampai umur saya 60 tahun. Selama kau tetap ada maksud saya.

Kutipan termasuk konflik antarkelas, karena konflik yang tercipta ketika terjadi perseteruan antar tokoh-tokoh berbeda kelas sosialnya. Abu yang menjadi buruh masih mampu bekerja hingga usia 60.

4. Dulu waktu saya masih bekerja di percetakan betul-betul sial saya. Hampir setiap jam saya kena marah.

Temuan konflik antarkelas sosial, menceritakan Abu selalu kena marah ketika bekerja.

5. Bersama ini kami semua meyatakan penghargaan dan terima kasih atas jasa, selama bekerja di sini. Bersama ini kami mneyatakan bahwa ..- sudah tidak bekerja di sini lagi. Keluar!! Terima kasih.

Temuan konflik antarkelas sosial tersebut, ketika tokoh Majikan dengan semena-mena memecat Abu dari pekerjaan.

\section{Unsur Frustrasi dalam Naskah Drama "Kocak-Kacik"}

1. Darim ayolah kita pulang, Darim. Aku sudah punya rumah yang bagus, taman yang bagus, kursi-kursi yang bagus, tempat tidur yang bagus, bantal yang bagus, istri yang bagus dan mulus. Darim, dimana kau. Darim. Pulang Darim!

Kutipan termasuk frustrasi dapat diartikan sebagai kekecewaan dalam diri individu, yang disebabkan oleh tidak tercapainya keinginan. Frustrasi juga bisa diartikan sebagai rasa kecewa yang mendalam, karena tujuan yang dikehendaki tak kunjung terlaksana. Eroh frustrasi, Darim tidak pulang kerumah.

2. Darim, kau boleh merajuk tapi jangan tinggalkan aku. Kalau kau pergi seperti sekarang ini, kepada siapa kau titipkan aku ini? Aku tidak mau di pelihara srigala.

Kutipan termasuk frustrasi dapat diartikan sebagai kekecewaan dalam diri individu, yang disebabkan oleh tidak tercapainya keinginan. Frustrasi juga bisa diartikan sebagai rasa kecewa yang mendalam, karena tujuan yang dikehendaki tak kunjung terlaksana. Rasa frustrasi Darim terhadap Eroh karena sifat dan tingkah lakunya seperti serigala.

3. Tak ada desa tak ada kota. Semua orang sama saja. Saat ini bumi sedang diliputi kata-kata yang banyaknya sangat menjijikkan seperti sedang dikerumuni singgatsinggat.

Kutipan di atas termasuk frustrasi, Darim kecewa kepada semua orang yang ditemuinya. Semuanya munafik, mau menang sendiri demi posisi aman.

4. Bebas? Kamu jangan main-main. Saya tahu nanti malam saya akan digantung.

Kutipan frustrasi di atas, keadaan memaksa Darim dihukum gantung karena Darim bernama Darim. Kecewa tokoh Hakim yang semena-mena memberi keputusan.

5. Kalau kau tidak sepaham, aku betul-betul akan lari. Dan kau akan kesepian. Tadi kau akan meninggalkan aku, sekarang aku akan meninggalkanmu. Kita tukar kedudukan. (TERIAK) bloon!

Kutipan termasuk frustrasi dapat diartikan sebagai kekecewaan dalam diri individu tokoh Eroh karena Darim masih saja bersikap jujur. Frustrasi juga bisa diartikan sebagai rasa kecewa yang mendalam, karena tujuan yang dikehendaki tak kunjung terlaksana. 


\section{Unsur Frustrasi dalam Naskah Drama "Kapai-Kapai”}

1. Baik kalau kamu mau enak-enak ngorok biar saya yang kerja. Apa dikira tidak bisa? Saya kira saya masih cukup montok untuk melipat seribu lelaki hidung belang di ketiak saya.

Kutipan termasuk frustrasi dapat diartikan sebagai kekecewaan dalam diri individu, yang disebabkan oleh tidak tercapainya keinginan. Frustrasi juga bisa diartikan sebagai rasa kecewa yang mendalam, karena tujuan yang dikehendaki tak kunjung terlaksana. Iyem yang kesal, Abu masih terlelap tidur.

2. Kamu lebih kasar lagi. Tidur sama istri kamu masih mimpi yang tidak-tidak. Tuh lihat tikar basah begitu. Kalau kau sudah bosan dengan saya bilang saja terus terang. Jangan sembunyi-sembunyi. Ayo, kau mimpi dengan siapa? Dengan si Ijah yang pantat gede itu? Bangsat!

Kutipan termasuk frustrasi dapat diartikan sebagai kekecewaan dalam diri individu, yang disebabkan oleh tidak tercapainya keinginan. Frustrasi juga bisa diartikan sebagai rasa kecewa yang mendalam, karena tujuan yang dikehendaki tak kunjung terlaksana. Tokoh Abu mimpi dan Iyem kecewa karena Abu masih memikirkan wanita lain bahkan ketika tidur.

3. Tidak. Abu jangan hiraukan. Hidup saja hidup. Habis perkara. Terlalu banyak pertanyaan untuk terlalu sedikit waktu.

Kutipan termasuk frustrasi dapat diartikan sebagai kekecewaan dalam diri individu, yang disebabkan oleh tidak tercapainya keinginan. Frustrasi juga bisa diartikan sebagai rasa kecewa yang mendalam, karena tujuan yang dikehendaki tak kunjung terlaksana. Tokoh Emak yang selalu membuat Abu tidak puas terhadap keinginan.

4. Ya, Tuhan. Ya, Tuhan. Dosa apalagi ini? Akan kau lempar ke mana amben ini? Ya Tuhan. Dan ini, gombal-gombal ini. Pakaian buruk ini. Tikar buruk ini. Bagian yang mana lagi yang akan kau sobek.

Temuan frustrasi di atas ketika tokoh Iyem rasa kecewa terhadap kehidupan yang miskin. Ada rasa kekecewaan mendalam pada Iyem.

5. Beras kita habis. Mamat dikeluarkan dari sekolahnya. Si Siti ternyata bunting. Lotre kita tidak kena lagi.

Kutipan termasuk frustrasi dapat diartikan sebagai kekecewaan dalam diri individu, yang disebabkan oleh tidak tercapainya keinginan. Frustrasi juga bisa diartikan sebagai rasa kecewa yang mendalam, karena tujuan yang dikehendaki tak kunjung terlaksana. Kekecewaan Iyem diakibatkan hutang dan kebutuhan ekonomi.

\section{Unsur Agresivitas dalam Naskah Drama "Kocak-Kacik"}

1. Ada yang berani kepada saya? Mau coba adu kekuatan?

Temuan kutipan agresivitas di atas adalah dorongan dasar yang dimiliki manusia, dengan tujuan menyakiti badan atau perasaan orang lain, terlebih perilaku yang bertujuan melukai atau mencelakakan orang lain. Bentuk agresivitas bisa berupa kekerasan secara fisik ataupun verbal.

2. Heh, ngomong apa? Awas kalau tiba-tiba ada yang dendam akan saya hukum.

Kutipan agresivitas di atas, tokoh Hakim marah kepada anggota sidang dan bertujuan melukai atau mencelakai.

3. Darim suamiku yang bloon, semua orang adalah pedagang, kasih saja mereka sogokan. 
Temuan kutipan agresivitas, tokoh Eroh memaksa Darim untuk memberi sogokan. Eroh berniat menyakiti prinsip dan perasaan Darim yang jujur.

4. Ya tolol namanya, ya bodoh namanya.

Eroh melukai perasaan Darim dengan memaki-maki. Temuan agresivitas dengan tujuan menyakiti badan atau perasaan orang lain.

5. Saya tidak punya ludah lagi, karena selama berumah tangga saya selalu meludahi wajahnya

Temuan agresivitas muncul ketika Eroh meludah ke wajah Darim sebagai suaminya. Agresivitas berupa kekerasan secara fisik ataupun verbal.

\section{Unsur Agresivitas dalam Naskah Drama "Kapai-Kapai"}

1. Monyong lu! Lelaki macam lu? Kerbau? Babi?

Temuan kutipan agresivitas di atas adalah dorongan dasar yang dimiliki manusia, dengan tujuan menyakiti badan atau perasaan orang lain, terlebih perilaku yang bertujuan melukai atau mencelakakan orang lain. Iyem menyakiti perasaan Abu dengan makian dan merendahkan Abu sebagai lelaki.

2. Jam berapa? Beduk sampai coblos dipalu orang juga kau masih enak-enak ngorok. Apa kamu tidak mau kerja?

Kutipan agresivitas di atas, Iyem yang memarahi Abu karena masih terus ngorok sambil memukuli Abu. Perilaku Iyem yang menyakiti Abu.

3. Kau memang betul-betul sandal dobol. Tapi, si Mamat mesti kerja. Dia sudah cukup besar. Dia seharusnya bukan sendal dobol macam bapaknya. Ya Tuhan, banjir. Banjiir. Banjiiiiirrrrr. (KELUAR)

Temuan kutipan agresivitas di atas adalah dorongan dasar yang dimiliki manusia, dengan tujuan menyakiti badan atau perasaan orang lain, terlebih perilaku yang bertujuan melukai atau mencelakakan orang lain.

4. Oh tentu. Tapi jangan terlalu bernafsu nanti hilang separuh tenagamu dihisap nafsumu sendiri.

Temuan kutipan agresivitas di atas adalah dorongan dasar yang dimiliki manusia, dengan tujuan menyakiti badan atau perasaan orang lain, terlebih perilaku yang bertujuan melukai atau mencelakakan orang lain. Dorongan dasar Abu dan Iyem untuk mencelakai anak kandungnya dengan berusaha membunuhnya.

5. Saya tak punya sedikitpun sisa tenaga. Semua ludas dihisap anak-anak saya. Bahkan si otong telah menghirup sumsum terakhir tulang betis saya. Kita berhenti saja.

Temuan kutipan agresivitas di atas adalah dorongan dasar yang dimiliki manusia, dengan tujuan menyakiti badan atau perasaan orang lain, terlebih perilaku yang bertujuan melukai atau mencelakakan orang lain. Abu dan Iyem berusaha menyakiti anaknya sendiri karena tidak mampu bertahan hidup.

\section{SIMPULAN}

Berdasarkan hasil penelitian tentang aspek relasi antarkelas sosial dalam naskah drama "Kocak-Kacik" dan "Kapai-Kapai" karya Arifin C. Noer, peneliti menyimpulkan bahwa dari 125 kutipan naskah drama "Kocak-Kacik" yang dianalisis terdiri atas unsur konflik antarkelas sosial sebanyak 25 atau 21,6\%, frustrasi 56 atau 48,7\%, agresivitas 34 atau $29,7 \%$. Aspek yang paling mendominasi adalah 48,7\% yaitu frustrasi. 
Pada naskah drama "Kapai-Kapai" karya Arifin C. Noer, peneliti menyimpulkan bahwa dari 115 kutipan, unsur konflik antarkelas sebanyak 46 atau 36,8\%, frustrasi 41 atau 32,8\%, agresivitas 38 atau 30,4\%. Unsur frustrasi muncul lebih banyak dibandingkan kedua unsur lainnya. Unsur frustrasi mendominasi paling banyak karena tokoh Abu dan Iyem selalu menghadapi kesulitan ekonomi sehingga unsur frustrasi meningkat.

\section{DAFTAR PUSTAKA}

Abercrombie, N. (2010). Kamus Sosiologi. Yogyakarta: Pustaka Pelajar.

Baron, R, A., \& Byrne. D. (2012). Psikologi sosial. Jakarta: Erlangga.

Kurniawan, H. (2012). Teori, Metode, dan Aplikasi Sosiologi Sastra. Yogyakarta: Graha Ilmu.

Moleong, L. J. (2004). Metodologi Penelitian Kualitatif. Bandung: Remaja Rosdakarya.

Nurgiyantoro, B. (2013). Teori pengkajian fiksi. Yogyakarta: Gajah Mada University Press.

Priyatni, E. T. (2010). Membaca sastra dengan ancangan literasi kritis. Jakarta: Bumi Aksara.

Riantiarno, N. (2011). Kitab teater tanya jawab seputar seni pertunjukan. Jakarta: Gramedia.

Ritzer, G., \& Goodman, D. J. (2011). Teori sosiologi modern. Jakarta: Prenada Media Group.

Semiawan, A., \& Saryono. (2010). Metodologi penelitian. Jakarta: Nuha Medika. 